\title{
Dental local anesthesia in Family Health Units: use, pain and associated factors
}

\author{
Anestesia local odontológica em Unidades de Saúde da Família: uso, dor e fatores associados \\ Etenildo Dantas Cabral ${ }^{1}$
}

DOI 10.5935/1806-0013.20150051

\section{ABSTRACT}

BACKGROUND AND OBJECTIVES: In spite of the relevance of controlling pain during dental procedures and of the fundamental role of Family Health Units in the Brazilian health system, there are few studies integrating both subjects. So, this study aimed at analyzing some aspects of dental anesthesia in Family Health Units of the city of Caruaru-PE.

METHODS: We have interviewed 372 adolescent and adult patients from 12 units, in the waiting room or close to it, after dental treatment, using a form with 14 questions. Pain was investigated with a numerical scale of 21 points ( 0 to 10 with 0.5 intervals).

RESULTS:Anesthesia was used in $16.1 \%$ of procedures. There has been pain during most anesthesias $(58.3 \%)$, with intensity of $1 \pm 1.2$, being more frequent when procedures were in the anterior oral region. For non-surgical invasive procedures, anesthesia was more used in adolescents, in procedures in the posterior oral region, when there was previous pain in the treated region and when the dentist asked patients about their preference. Also for these procedures, pain during treatment as a whole was more frequent and more severe when anesthesia was used.

CONCLUSION:Dental anesthesia is rarely used in these units and pain during anesthesia is frequent, however of low intensity. During non-surgical invasive procedures, its use is associated to some characteristics of patients and treatments, but not to a painless or less painful treatment.

Keywords: Acute pain, Dental anesthesia, Local anesthesia, Primary health assistance.

1. Universidade Federal de Pernambuco, Recife, PE, Brasil.

Submitted in July 14, 2015.

Accepted for publication in October 13, 2015.

Conflict of interests: none- Sponsoring sources: None.

Correspondence to:

Etenildo Dantas Cabral

Av. Prof. Moraes Rego, 1235 - Cidade Universitária

50670-901 Recife, PE, Brasil.

E-mail: etenildo@gmail.com

(C) Sociedade Brasileira para o Estudo da Dor
RESUMO

JUSTIFICATIVA E OBJETIVOS: Apesar da importância do controle da dor em odontologia e do papel fundamental das Unidades de Saúde da Família no sistema de saúde do Brasil, são raros os estudos que integram esses dois assuntos. Portanto, o presente estudo objetivou analisar alguns aspectos relativos à anestesia odontológica em Unidades de Saúde da Família de Caruaru-PE.

MÉTODOS: Entrevistou-se 372 pacientes adolescentes e adultos atendidos em 12 unidades, na sala de espera ou proximidades, após o atendimento odontológico, com um formulário contendo 14 perguntas. A dor foi investigada utilizando uma escala numérica de 21 pontos ( 0 a 10 , intervalos de 0,5$)$.

RESULTADOS: A anestesia foi utilizada em $16,1 \%$ dos atendimentos. Ocorreu dor na maioria das anestesias $(58,3 \%)$, com intensidade de $1 \pm 1,2$, sendo mais frequente quando o procedimento foi na região bucal anterior. Para os procedimentos invasivos nãocirúrgicos, a anestesia foi mais usada em adolescentes, procedimentos na regiáo bucal posterior, quando havia dor prévia na região tratada e quando o dentista perguntava ao paciente sua preferência. Também para esses procedimentos, a dor do tratamento como um todo foi mais frequente e de maior intensidade quando anestesia foi usada.

CONCLUSÂO: Anestesia odontológica é pouco utilizada nessas unidades e a dor durante a mesma é frequente, porém, de baixa intensidade. Em procedimentos invasivos nãocirúrgicos seu uso está associado a algumas características do paciente e do atendimento, mas não a um tratamento sem dor ou com dor de menor intensidade.

Descritores: Anestesia dentária, Anestesia local, Atenção primária à saúde, Dor aguda.

\section{INTRODUCTION}

Pain in dentistry may be associated to a disease affecting the oral cavity and, in these cases, clinical procedures are decisive for its eradication. It may also be associated to the dental procedure itself, very often needing local anesthetic solution administration to control such sensation. However, studies have shown that some patients are afraid of anesthesia ${ }^{1}$ and others consider it more painful than the treatment itself $^{2}$, in addition to the fact that anesthetic injection may fail in promoting adequate anesthesia for the dental procedure ${ }^{3}$.

Other aspects of dental local anesthesia include the effect of 
anesthetic injection pressure on anesthetic pain ${ }^{4}$, the evaluation and comparison among techniques ${ }^{5,6}$, the efficacy of anesthetic agents ${ }^{7,8}$ etc. Frequency and factors influencing professionals to use or not anesthesia for nonsurgical invasive procedures, such as restorations, are absolutely scarce ${ }^{9}$, as well as there are no literature studies evaluating anesthetic pain in basic attention services of the Brazilian health system, such as Family Health Units (USF).

These health units in general assist destitute communities which, consequently, have no good oral health conditions and so have further need for clinical treatments and interventions. So, the need to control pain is frequent in dental assistance to such communities, which increases the importance of studies addressing pain and anesthesia in such health services.

In light of the above, this study aimed at identifying and evaluating some aspects regarding dental local anesthesia in USF of the city of Caruaru-PE.

\section{METHODS}

This is an epidemiologic, observational, cross-sectional and analytical study carried out in the urban zone of the city of Caruaru, Pernambuco, from May to September 2013, according to the ethical principles of the Declaration of Helsinki.

Sample was made up of 372 adolescent and adult patients (12 to 59 years of age), assisted in 12 USF (from 20 of the urban zone of the city with oral health teams), in a total of 31 patients per unit. Sample was by conglomerate (double stage), where USF were the groups. So, USF were selected by simple and randomized sampling, and from those, patients were selected. Sample size was defined by the program Power Analysis and Sample Size (version 2005).

Data were collected in the waiting room of the USF or close to it, according patients' preference, after dental assistance, by means of a standardized interview with a form with 14 questions. Anesthetic pain and pain during treatment as a whole were investigated using numeric evaluation scales with 21 points (from zero to 10 with 0.5 intervals) ${ }^{10}$ and anxiety was defined by Corah's the Dental Anxiety Scale (DAS) ${ }^{11}$.

DAS checks the level of anxiety with the dental treatment by means of 4 questions, each one with five alternative answers which score from 1 to 5 and classify the level of anxiety in null (up to 4 points), low (5 to 9 points), moderate (10 to 14 points) and exacerbated (15 to 20 points).

\section{Statistical analysis}

Data were analyzed by the statistical package SPSS (version 20). Chi-square, likelihood ratio and Fisher Exact tests were used for categorical variables and Mann-Whitney test was used for quantitative variables. For all tests, significance level was $5 \%$.

This study was approved by the Ethics Committee of the Associação Caruaruense de Ensino Superior - Faculdade ASCES (CAAE 15037513.8.0000.5203) and a pilot study has tested and adjusted methods and logistics.

\section{RESULTS}

From 372 treated patients, anesthesia was used in just 60 (16.1\%). For nonsurgical invasive procedures (248) there have been cases with anesthesia (11.3\%) and without anesthesia $(88.7 \%)$, as shown in table 1 .

Table 1. Frequency of dental anesthesia according to the type of procedure

\begin{tabular}{lccccccc}
\hline $\begin{array}{l}\text { Procedures to which } \\
\text { patients were submit- } \\
\text { ted, in categories }\end{array}$ & \multicolumn{3}{c}{$\begin{array}{c}\text { Use of anesthesia for } \\
\text { treatment }\end{array}$} & \multicolumn{2}{c}{ Total } \\
& \multicolumn{1}{c}{ No } & $\%$ & $\mathrm{n}$ & $\%$ & $\mathrm{n}$ & $\%$ \\
\hline $\begin{array}{l}\text { Noninvasive proce- } \\
\text { dures * }\end{array}$ & 92 & 100.0 & 0 & 0 & 92 & 100.0 \\
$\begin{array}{l}\text { Nonsurgical invasive } \\
\text { procedures ** }\end{array}$ & 220 & 88.7 & 28 & 11.3 & 248 & 100.0 \\
$\begin{array}{l}\text { Surgical invasive pro- } \\
\text { cedures *** }\end{array}$ & 0 & 0 & 32 & 100.0 & 32 & 100.0 \\
\begin{tabular}{l} 
Total \\
\hline
\end{tabular} & 312 & 83.9 & 60 & 16.1 & 372 & 100.0 \\
\hline
\end{tabular}

${ }^{*}$ clinical evaluation, polishing, sealant, varnish or fluoride application, drug prescription; ** crown opening, filling/restoration, tartar removal, stitches removal; *** tooth extraction, surgeries and suture.

Table 2 shows that the use or not of anesthesia for nonsurgical invasive procedures was associated to some patients and treatment characteristics, so that anesthesia was significantly more used $(\mathrm{p}<0.05)$ in adolescent patients, for posterior oral region procedures, when there was previous pain in the treated region and when the dentist would ask patients about their preference with regard to anesthesia.

There has been pain in most anesthesias (in 35 out of 60 cases, or $58.3 \%$ ), with mean intensity of $1 \pm 1.2$ and maximum of 5 , in a scale of 0 to 10 . With the help of table 3 it was possible to observe that the presence of pain was associated $(\mathrm{p}<0.05)$ just to the treated oral region, among all evaluated variables, being pain induced by anesthesia more frequent when the anterior region was treated. It is important to highlight that the use of topical anesthesia was not associated to lack of anesthetic pain; in fact, this pain was more frequent when topical anesthetics were used, although without significant difference $(\mathrm{p}=0.102)$. Table 4 shows that patients have felt pain during treatment as a whole in $71.4 \%$ of cases with anesthesia when procedure was nonsurgical and invasive, and in $59.4 \%$ of surgical procedures, without significant difference. It also shows that pain during nonsurgical invasive procedures was significantly less frequent in cases without anesthesia $(44.5 \%)$ as compared to those with anesthesia.

Pain intensity during treatment as a whole in anesthetized cases has varied from zero to 10 , with mean of $1.6 \pm 1.9$ and was not significantly different between surgical and nonsurgical invasive procedures ( $\mathrm{p}=0.227$ by Mann-Whitney test). However, mean pain intensity during nonsurgical invasive procedures was significantly higher in cases with anesthesia $(2.1 \pm 2.5)$ as compared to those without anesthesia $(1.1 \pm 1.8)$ ( $\mathrm{p}=0.004$ by Mann-Whitney test). 
Table 2. Frequency of use of dental anesthesia for nonsurgical invasive procedures, according to patients and treatment characteristics

\begin{tabular}{|c|c|c|c|c|c|}
\hline \multirow{3}{*}{$\begin{array}{l}\text { Patients and treatment } \\
\text { characteristics }\end{array}$} & \multicolumn{4}{|c|}{ Use of anesthesia } & \multirow[t]{3}{*}{$p$ value } \\
\hline & \multicolumn{2}{|c|}{ No } & \multicolumn{2}{|c|}{ Yes } & \\
\hline & $\mathrm{n}$ & $\%$ & $\mathrm{n}$ & $\%$ & \\
\hline Gender & & & & & $p^{1}=0.164$ \\
\hline Male & 58 & 93.5 & 4 & 6.5 & \\
\hline Female & 162 & 87.1 & 24 & 12.9 & \\
\hline Age group (years) & & & & & $\mathrm{p}^{2}=0.032$ \\
\hline 12 to 18 & 26 & 74.3 & 9 & 25.7 & \\
\hline 19 to 39 & 130 & 90.9 & 13 & 9.1 & \\
\hline 40 to 59 & 64 & 91.4 & 6 & 8.6 & \\
\hline Treated dental arch & & & & & $\mathrm{p}^{1}=0.200$ \\
\hline Upper & 93 & 86.1 & 15 & 13.9 & \\
\hline Lower & 70 & 87.5 & 10 & 12.5 & \\
\hline Both & 57 & 95 & 3 & 5 & \\
\hline Treated oral region & & & & & $\mathrm{p}^{1}=0.001$ \\
\hline Anterior & 61 & 95.3 & 3 & 4.7 & \\
\hline Posterior & 105 & 81.4 & 24 & 18.6 & \\
\hline Both & 54 & 98.2 & 1 & 1.8 & \\
\hline $\begin{array}{l}\text { Previous pain in treated re- } \\
\text { gion }\end{array}$ & & & & & $\mathrm{p}^{3}=0.010$ \\
\hline No & 193 & 91 & 19 & 9 & \\
\hline Yes & 27 & 75 & 9 & 25 & \\
\hline $\begin{array}{l}\text { Previous pain in other head } \\
\text { region different from the } \\
\text { treated }\end{array}$ & & & & & $\mathrm{p}^{3}=0.481$ \\
\hline No & 203 & 89 & 25 & 11 & \\
\hline Yes & 17 & 85 & 3 & 15 & \\
\hline Level of dental anxiety* & & & & & $\mathrm{p}^{2}=0.430$ \\
\hline Null & 10 & 90.9 & 1 & 9.1 & \\
\hline Low & 115 & 91.3 & 11 & 8.7 & \\
\hline Moderate & 70 & 87.5 & 10 & 12.5 & \\
\hline Exacerbated & 25 & 80.6 & 6 & 19.4 & \\
\hline Fear of anesthesia & & & & & $\mathrm{p}^{1}=0.125$ \\
\hline No & 113 & 91.1 & 11 & 8.9 & \\
\hline A little & 44 & 93.6 & 3 & 6.4 & \\
\hline Somewhat & 38 & 84.4 & 7 & 15.6 & \\
\hline A lot & 25 & 78.1 & 7 & 21.9 & \\
\hline $\begin{array}{l}\text { Check of patients' prefe- } \\
\text { rence with regard to anes- } \\
\text { thesia }\end{array}$ & & & & & $p^{3}=0.000$ \\
\hline No & 211 & 92.1 & 18 & 7.9 & \\
\hline Yes & 9 & 47.4 & 10 & 52.6 & \\
\hline
\end{tabular}

Table 3. Frequency of dental anesthesia pain, according to patients and treatment characteristics

\begin{tabular}{|c|c|c|c|c|c|}
\hline \multirow{3}{*}{$\begin{array}{l}\text { Patients and treatment cha- } \\
\text { racteristics }\end{array}$} & \multicolumn{4}{|c|}{ Anesthetic pain } & \multirow[t]{3}{*}{$\mathrm{p}$ value } \\
\hline & \multicolumn{2}{|c|}{ No } & \multicolumn{2}{|c|}{ Yes } & \\
\hline & $\mathrm{n}$ & $\%$ & $\mathrm{n}$ & $\%$ & \\
\hline Gender & & & & & $\mathrm{p}^{1}=0.961$ \\
\hline Male & 7 & 41.2 & 10 & 58.8 & \\
\hline Female & 18 & 41.9 & 25 & 58.1 & \\
\hline Age group (years) & & & & & $\mathrm{p}^{1}=0.742$ \\
\hline 12 to 18 & 4 & 33.3 & 8 & 66.7 & \\
\hline 19 to 39 & 12 & 41.4 & 17 & 58.6 & \\
\hline 40 to 59 & 9 & 47.4 & 10 & 52.6 & \\
\hline Treated dental arch & & & & & $\mathrm{p}^{2}=0.210$ \\
\hline Upper & 10 & 31.3 & 22 & 68.7 & \\
\hline Lower & 12 & 54.5 & 10 & 45.5 & \\
\hline Both & 3 & 50 & 3 & 50 & \\
\hline Treated oral region & & & & & $\mathrm{p}^{2}=0.005$ \\
\hline Anterior & 1 & 7.1 & 13 & 92.9 & \\
\hline Posterior & 21 & 51.2 & 20 & 48.8 & \\
\hline Both & 3 & 60 & 2 & 40 & \\
\hline $\begin{array}{l}\text { Previous pain in treated re- } \\
\text { gion }\end{array}$ & & & & & $\mathrm{p}^{1}=0.542$ \\
\hline No & 16 & 39.0 & 25 & 61.0 & \\
\hline Yes & 9 & 47.4 & 10 & 52.6 & \\
\hline
\end{tabular}

Previous pain in other head region different from the $\mathrm{p}^{3}=0.634$ treated

No
Yes

Level of dental anxiety *

$p^{2}=0.261$

$\begin{array}{lcccc}\text { Null } & 2 & 100 & 0 & 0.0 \\ \text { Low } & 11 & 37.9 & 18 & 62.1 \\ \text { Moderate } & 8 & 38.1 & 13 & 61.9 \\ \text { Exacerbated } & 4 & 50.0 & 4 & 50.0\end{array}$

Fear of anesthesia

No

$\begin{array}{llll}13 & 44.8 & 16 & 55.2\end{array}$

A little

Somewhat

$\begin{array}{llll}3 & 27.3 & 8 & 72.7\end{array}$

A lot

$\begin{array}{llll}4 & 36.4 & 7 & 63.6\end{array}$

$\begin{array}{llll}5 & 55.6 & 4 & 44.4\end{array}$

Use of topic anesthesia**

$\mathrm{p}^{3}=0.102$

\begin{tabular}{ccccc} 
No & 7 & 63.6 & 4 & 36.4 \\
Yes & 17 & 35.4 & 31 & 64.6 \\
\hline $\mathrm{p}^{1}$ = Pearson Chi-square; $\mathrm{p}^{2}$ = Likelihood Ratio, $\mathrm{p}^{3}$ = Fischer Exact. \\
${ }^{*}$ According to Corah Dental Anxiety Scale. ${ }^{* *} 1$ patient did not know whether
\end{tabular}


Table 4. Pain during treatment as a whole, according to the use or not of anesthesia and according to type of invasive procedure

\begin{tabular}{|c|c|c|c|c|c|c|}
\hline \multicolumn{2}{|c|}{ Use of anesthesia and type of procedure } & \multicolumn{4}{|c|}{ Pain during treatment } & \multirow[t]{3}{*}{$p$ value* } \\
\hline & \multirow[b]{2}{*}{$\mathrm{n}$} & \multicolumn{2}{|c|}{ No } & \multicolumn{2}{|c|}{ Yes } & \\
\hline & & $\%$ & $\mathrm{n}$ & $\%$ & & \\
\hline \multirow[t]{2}{*}{ W/o anesthesia } & Nonsurgical & 122 & 55.5 & 98 & 44.5 & $0.007^{\S}$ \\
\hline & Surgical & - & - & - & - & \\
\hline \multirow[t]{2}{*}{ With anesthesia } & Nonsurgical & 8 & 28.6 & 20 & 71.4 & 0.329 \\
\hline & Surgical & 13 & 40.6 & 19 & 59.4 & \\
\hline
\end{tabular}

${ }^{*}$ Pearson Chi-square test; $\S$ = comparing nonsurgical without anesthesia versus with anesthesia.

\section{DISCUSSION}

As compared to available literature data, the frequency of local anesthetics use in the studied population was low, both general frequency and that specific for nonsurgical invasive procedures. In a Finland ${ }^{12}$ study, for example, in the age group with the lowest frequency of use, anesthesia was used in $38 \%$ of restorative procedures. Local anesthesia for dental care varies among cultures. Americans use more anesthesia than Nordics and those more than Chinese ${ }^{13}$.

Features of dental service institutions may also influence the frequency of local anesthetics use, not simply for being public or private, but also because there are several aspects of their operations. A study has found that anesthesia for restorative procedures was more frequent in the public service as compared to private service ${ }^{9}$, but in this public service adult patients do not have totally free assistance. It might be that the low frequency found in our study is influenced by the fact that dentists have quotas of patients to be treated, so that they are available for other jobs the sooner they meet such quota. It is probable that they avoid wasting time with anesthesia for nonsurgical invasive procedures. Obviously, this speculation deserves further studies.

It does not seem adequate to think that the low prevalence of anesthesia during nonsurgical invasive procedures was due to patients' preference, since in the vast majority of cases dentists have not asked patients about their preference. In addition, it was observed that exactly when dentists asked that question, the use of anesthesia was more frequent.

In addition to checking patients' preference, other variables were associated to the use or not of anesthesia for nonsurgical invasive procedures, such as age, treated oral region and the presence or not of previous pain in treated region. These results are similar to other study ${ }^{12}$ which points to more frequent use of anesthesia in adolescents and posterior oral region, however without difference with regard to patients' gender.

As to the presence or not of previous pain in the treated region, it was to be expected a more frequent use of anesthesia in cases of pain. In these cases, it is well possible that there is a peripheral sensitization by an inflammatory process, with increased responsiveness to stimuli and decreased activation threshold ${ }^{14}$. So, if dentists start a nonsurgical invasive procedure without anesthesia it is to be assumed that soon after they decide to use it due to patient's pain report.
The high frequency of anesthesia-induced pain found in our study reinforces literature data with regard to the painful potential of such procedure. Its use has already been identified as one of the strongest predictors of pain during dental treatment ${ }^{15}$ and was mentioned by $30 \%$ of patients as reason of pain during tooth extractions ${ }^{10}$.

In spite of this high frequency, anesthesia-related pain was mild, similarly to other studies ${ }^{16,17}$. However, the adequate posture would not be to expect patients to stand the pain just because it is mild. Dentists and dentistry should always work to offer a painless treatment.

These efforts have to include investigation on technique-related variables which might influence anesthetic pain, since there is a clear lack of such information in the literature. In this sense, our study contribution was to show that anterior oral region is more susceptible to this pain, which was also found by a previous study ${ }^{5}$. Anxiety with anesthesia might influence perceived pain during such procedure ${ }^{17}$, although anxiety with dental treatment and fear of anesthesia were not significant in our study. Patients' gender really does not seem to determine anesthetic pain ${ }^{18}$.

With regard to anesthetic technique-related variables, our study confirms previous studies about the ineffectiveness of topical anesthetics to eliminate anesthetic pain. They might even decrease needle insertion pain intensity, but not eliminate it, and for pain at anesthetic injection they are even less effective, especially if dentists do not wait long enough for the anesthetic to $\mathrm{act}^{18}$. As already discussed, working circumstances of studied institutions do not seem to favor the waiting for this effect.

Anesthesia has also not provided a painless treatment for most anesthetized patients. In fact, full effectiveness is in general not reported and this is why new anesthetic drugs and techniques continue to be tested ${ }^{8,19}$. However, the situation was more severe in cases of nonsurgical procedures, given the presence of pain during the procedure as a whole and the fact that it was more severe when anesthesia was used. It really seems that anesthetic pain is worse than pain of the procedure itself ${ }^{2}$. This might be dentists' understanding, due to their clinical experience, and the reason why they seldom use anesthesia for such procedures. This same fear of anesthetic pain may also lead dentists to use anesthesia only when patients refer pain during the procedure. This puts an end to any possibility of a totally painless treatment. 


\section{CONCLUSION}

Local dental anesthesia is seldom used in USFs of Caruaru, anesthetic pain is frequent, especially in the anterior oral region, however its intensity is low.

In nonsurgical invasive procedures its use is associated to some patients and treatment characteristics, but not to a painless or less painful dental treatment. So, dentists and managers of evaluated institutions have to review dental anesthesia practices to favor painless treatments.

\section{ACKNOWLEDGMENTS}

To the students of Faculdade Asces: Diná Cardoso da Silva, Ítala Kiev Muniz, José Marcelo Vasconcelos, Plínio Frederico Maciel and Severina Menezes Castro for their held during data collection.

\section{REFERENCES}

1. Ujaoney S, Mamtani M, Thakre T, Tote J, Hazarey V, Hazarey P, et al. Efficacy trial of Camouflage Syringe to reduce dental fear and anxiety. Eur J Paediatr Dent. 2013;14(4):273-8.

2. Siqueira AM, Oliveira PC, Shcaira VR, Ambrosano GM, Ranali J, Volpato MC. Relação entre ansiedade e dor em anestesia local e procedimentos periodontais. Rev Odontol UNESP. 2006;35(2):171-4.

3. Arantes V, Posso I, Arantes G, Monteiro Júnior A. Falha na anestesia do dente canino inferior. Rev Dor. 2009;10(1):44-6.

4. Kudo M. Initial injection pressure for dental local anesthesia: effects on pain and anxiety. Anesth Prog. 2005;52(3):95-101.

5. Kaufman E, Epstein JB, Naveh E, Gorsky M, Gross A, Cohen G. A survey of pain, pressure, and discomfort induced by commonly used oral local anesthesia injections.
Anesth Prog. 2005;52(4):122-7.

6. Saxena P, Gupta SK, Newaskar V, Chandra A. Advances in dental local anesthesia techniques and devices: an update. Natl J Maxillofac Surg. 2013;4(1):19-24.

7. Sancho-Puchades M, Vílchez-Pérez MA, Valmaseda-Castellón E, Paredes-García J, Berini-Aytés L, Gay-Escoda C. Bupivacaine $0.5 \%$ versus articaine $4 \%$ for the removal of lower third molars. A crossover randomized controlled trial. Med Oral Patol Oral Cir Bucal. 2012;17(3):e462-8.

8. Vílchez-Pérez MÁ, Sancho-Puchades M, Valmaseda-Castellón E, Paredes-García J, Berini-Aytés L, Gay-Escoda C. A prospective, randomized, triple-blind comparison of articaine and bupivacaine for maxillary infiltrations. Med Oral Patol Oral Cir Bucal. 2012;17(2):e325-30.

9. Palotie U, Vehkalahti MM. Use of local anesthesia in restorative treatment for adult in Finland. Acta Odontol Scand. 2007;65(3):129-33.

10. Cabral ED, Alves GG, Souza GC. Dor durante o atendimento odontológico em unidades de saúde da família do município de Caruaru-PE. Rev Dor. 2013;14(2):100-5.

11. van Wijk AJ, Makkes PC. Highly anxious dental patients report more pain during dental injections. Br Dent J. 2008;205(3):E7; discussion 142-3.

12. Palotie U, Vehkalahti M. Restorative treatment and use of local anesthesia in free and subsidized public dental services in Helsinki, Finland. Acta Odontol Scand. 2003;61(4):252-6

13. Moore R, Brødsgaard I, Mao TK, Miller ML, Dworkin SF. Acute pain and use of local anesthesia: tooth drilling and childbirth labor pain beliefs among Anglo-Americans, Chinese, and Scandinavians. Anesth Prog. 1998;45(1):29-37.

14. Sessle BJ. Mecanismos periféricos e centrais da dor orofacial e suas correlaçôes clínicas. In: Alves Neto O, Costa CM de C, Siqueira JTT, Teixeira MJ, editors. Dor: princípios e prática. Porto Alegre: Artmed; 2009. 189-204p.

15. Tickle M, Milsom K, Crawford FI, Aggarwal VR. Predictors of pain associated with routine procedures performed in general dental practice. Community Dent Oral Epidemiol. 2012;40(4):343-50.

16. Costa FA, Souza LM, Groppo F. Comparaçáo da intensidade de dor em bloqueios do nervo alveolar inferior. Rev Dor. 2013;14(3):165-8.

17. van Wijk A, Lindeboom JA, de Jongh A, Tuk JG, Hoogstraten J. Pain related to mandibular block injections and its relationship with anxiety and previous experiences with dental anesthetics. Oral Surg Oral Med Oral Pathol Oral Radiol. 2012;114(5 Suppl):S114-6.

18. Bhalla J, Meechan JG, Lawrence HP, Grad HA, Haas DA. Effect of time on clinical efficacy of topical anesthesia. Anesth Prog. 2009;56(2):36-41.

19. Makade CS, Shenoi PR, Gunwal MK. Comparison of acceptance, preference and efficacy between pressure anesthesia and classical needle infiltration anesthesia for dental restorative procedures in adult patients. J Conserv Dent. 2014;17(2):169-74. 